Winter 2010

\title{
Human Security with an Asian Face?
}

Sung Won Kim

Ministry of Foreign Affairs and Trade, Republic of Korea

Follow this and additional works at: https://www.repository.law.indiana.edu/ijgls

Part of the International Law Commons, and the Law and Politics Commons

\section{Recommended Citation}

Kim, Sung Won (2010) "Human Security with an Asian Face?," Indiana Journal of Global Legal Studies: Vol. 17 : Iss. 1 , Article 5.

Available at: https://www.repository.law.indiana.edu/ijgls/vol17/iss1/5

This Symposium is brought to you for free and open access by the Law School Journals at Digital Repository @ Maurer Law. It has been accepted for inclusion in Indiana Journal of Global Legal Studies by an authorized editor of Digital Repository @ Maurer Law. For more information, please contact rvaughan@indiana.edu.

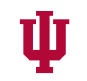

JEROME HALL LAW LIBRARY INDIANA UNIVERSITY Maurer School of Law
Bloomington 


\title{
Human Security with an Asian Face?
}

\author{
SUNG WON KIM*
}

\section{INTRODUCTION}

The twenty-first century may well be remembered as the Asian century. ${ }^{1}$ The rise of Asian countries in world politics creates conditions for the possible emergence of an Asian-influenced international system and an Asian perspective on international law and global governance, which, together, can be called an "Eastphalian order." The development of an Eastphalian order will not only reflect the interests of Asian countries and peoples, but also will contain a vision for international law and global governance that will affect world affairs and globalization in the coming decades.

The possible emergence of an Eastphalian order provides food for thought for Asian countries to reflect on Western-dominated rules, systems, and institutions of international law and global governance that have shaped the development of Asia for many decades. Since at least the birth of the Westphalian state system in 1648, Western countries have shaped international relations through their material power and political interests, as evidenced by imperialism and colonialism. Asia was a main target of Western imperialism and colonialism, and the Western imperial powers exploited and damaged many Asian countries. Considering the historical experiences of Asian countries, the rise of Asian material power and political influence in global affairs might herald an opportunity for Asian countries to effect lasting reforms in international relations according to Asian-preferred ideas, particularly with respect to how international law and global governance function. The Asian region is already beginning to enjoy the material benefits of the growth of Asian economic and political power,

* Second Secretary of International Legal Affairs Division, Treaties Bureau, Ministry of Foreign Affairs and Trade, Republic of Korea; Member, Korean Society of International Law. The views expressed in this article are mine and do not in any way describe or represent the views and policies of the Republic of Korea.

1. David P. Fidler, The Asian Century: Implications for International Law, 9 SING. Y.B. INT'L L. 1, 1 (2005).

Indiana Journal of Global Legal Studies Vol. 17 \#1 (Winter 2010)

(C) Indiana University Maurer School of Law 
particularly with respect to the widely acknowledged emergence of two Asian great powers, China and India. However, whether these Asian great powers and other countries in the region will shape or transform the prevailing ideas alive in twenty-first century international politics remains to be seen.

As noted frequently in this symposium ${ }^{2}$ and elsewhere, ${ }^{3}$ Asian countries have long stressed the principles of sovereignty and noninterference in the domestic affairs of sovereign states, whether collectively through regional organizations or bilaterally in their respective foreign policies. These principles are neither new nor distinctively Asian because they find identical counterparts in the development of the Westphalian international system and in the Charter of the United Nations. Asian commitment to the principles of sovereignty and noninterference certainly contrasts with post-Cold War Western-inspired efforts to limit sovereignty and qualify the principle of noninterference. The West has pursued these aims by advancing purported rules of post-Westphalian international law, such as human rights, humanitarian intervention, the responsibility to protect, and the right to democratic government. At some level, all of these rules require international community scrutiny of and interference with the domestic affairs of many states.

The combination of Asia's growing material power and its longstanding commitment to principles of sovereignty and noninterference raises questions about the future of post-Cold War concepts of international law and global governance, especially the concept of "human security." This article analyzes what the emergence of an Eastphalian order might mean for efforts to improve human security. The concept of human security grew in importance during the post-Cold War period, drawing both adherents and detractors to its attempt to shift security thinking away from the state and toward individuals. Human security also seemed to resonate with concerns about how globalization rendered traditional notions of sovereignty and security less relevant, creating the need for more innovative ways to think about and achieve security. Some scholars have expressed worry that the rise of Asian countries in world politics may threaten the future

2. See Tom Ginsburg, Eastphalia as the Perfection of Westphalia, 17 IND. J. GLOBAL LEGAL STUD. 27, 28, 34 (2010); David P. Fidler \& Sumit Ganguly, India and Eastphalia, 17 IND. J. Global Legal STud. 147, 150-51 (2010); Men Honghua, East Asian Order Formation and Sino-Japanese Relations, 17 IND. J. GLOBAL LEGAL STUD. 47, 68-69 (2010); Chang-fa Lo, Values to be Added to Eastphalia by the Emerging China, 17 IND. J. GLOBAL LEGAL STUD. 13, 16-17 (2010).

3. Sung Won Kim, David P. Fidler \& Sumit Ganguly, Eastphalia Rising? Asian Influence and the Fate of Human Security, 26 WORLD POL'Y J. 53, 53 (2009). 
of human security as a concept and policy objective. ${ }^{4}$ Whether such a threat actually emerges depends on how Asian countries perceive human security in light of their philosophical heritage, political principles, and material interests. Predicting the trajectory of human security in an Eastphalian order proves a very complicated task.

This article proceeds in five parts. First, it briefly analyzes the concept of human security and its relevance to international law and global governance in the early twenty-first century. Second, the article explores why the Asian region might constitute an interesting laboratory for the human security project despite the longstanding commitment of Asian countries to the principles of sovereignty and noninterference. Third, it looks at the relevance of Confucian thinking in order to see whether this powerful philosophical heritage of many Asian societies contains insight that may help shape the evolution of Asian perspectives on human security. Fourth, the article briefly considers Japan's efforts to embrace the human security concept in its foreign policy, especially its development assistance. Finally, it considers whether the emergence of a more Asian-centric international system can develop a distinctive Asian contribution to the problems the concept of human security was developed to address.

\section{THE CONCEPT OF HUMAN SECURITY AND ITS IMPACT ON THINKING ABOUT SECURITY, INTERNATIONAL LAW, AND GLOBAL GOVERNANCE}

Traditional notions of security, shaped largely by the structure and dynamics of the Cold War, were concerned mainly with a state's ability to counter external military threats from rival states. The conventional view of security is largely dependent on accepting the dominance of the Westphalian state system, which is composed of states as the dominant actors. Under traditional security ideas, the only real security concern is for a state to maintain its survival, power, and political influence against external threats from rival states.

After the end of the Cold War and the subsequent impact of a new phase of globalization, the rise of new types of security threats challenged the traditional perspective on security, with its focus on the survival of states. These new threats included such dangers as environmental pollution, transnational terrorism, massive population movements, and infectious diseases, such as HIV/AIDS..$^{5}$ These new, nontraditional security threats pose dangers not only to the security of

4. See, e.g., id.

5. Comm'n on Human Security, Human Security Now, at 5 (May 1, 2003) [hereinafter Human Security Now], available at http://www.humansecurity-chs.org/finalreport/ English/FinalReport.pdf. 
the state (national security), but also to the security of individuals and communities (human security). Behind the perceived rise of these new security threats is the idea that the security of individuals cannot be protected by the military capabilities of states because these capabilities do not provide defenses against transnational dangers accelerated by globalization. In these circumstances, the security conditions of individual human beings are more vulnerable to newly emerging security threats, creating the need to think about security policy in very different ways.

The idea of human security was most famously introduced in the United Nations Development Programme (UNDP) Report of $1994 .^{6}$ The UNDP asserted that human security has two main elements: protection from (1) threats, such as hunger, disease, and repression; and (2) sudden and harmful disruptions in the patterns of daily life. ${ }^{7}$ The UNDP also asserted that globalization creates the need to think about security in human rather than state-centric terms: "In the globalizing world of shrinking time, shrinking space and disappearing borders, people are confronting new threats to human security-sudden and harmful disruption in the pattern of daily life." According to the UNDP, there are seven specific elements that comprise human security: (1) economic security, (2) food security, (3) health security, (4) environmental security, (5) personal security, (6) community security, and (7) political security. ${ }^{9}$

The human security concept seeks to reframe the pursuit of security by placing individual human beings at the center of security concerns. ${ }^{10}$ Tigerstrom indicates that the human-centered focus of the human security concept demands explicit attention to the needs and interests of individuals and gives analytical and moral priority to individuals' needs and interests over those of states. ${ }^{11}$ She also points out that the core of this human-centered approach is the normative priority of people's security, especially in relation to states' security. According to Fidler, the theoretical foundation of human security is rooted in the theory of

6. U.N. Dev. Programme, Human Development Report 1994: New Dimensions of Human Security, at 22 (1994) [hereinafter UNDP Report 1994], available at http://hdr.undp.org/en/reports/global/hdr1994/.

7. Id. at 23 .

8. U.N. Dev. Programme, Human Development Report 1999: Globalization with a Human Face, at 3 (1999) [hereinafter UNDP Report 1999], available at http:/hdr.undp.org/en/reports/global/hdr1999/.

9. UNDP Report 1994, supra note 6, at 24-25.

10. BARBARA VON TIGERSTROM, HUMAN SECURITY AND INTERNATIONAL LAW: PRospects AND PRoBlems 8 (2007).

11. Id. at 62 . 
social constructivism. ${ }^{12}$ Fidler notes that "social constructivists would focus, thus, on the ideational move away from the narrow, realist concept of national security toward more expansive notions of security, such as human security, a shift that illustrates the power of ideas to shape how humans socially construct their relations globally."13

Under human security, a security threat can be construed as any menace to "the quality of life of individuals." 14 Thus, human security regards the problems of hunger, poverty, environmental degradation, underdevelopment, infectious diseases, and even natural disasters (such as tsunamis) as the most urgent security threats to the daily life of individuals. ${ }^{15}$ Human security highlights the interdependence of these various security concerns. For instance, if one group or individual is threatened, many other communities are also likely at risk. Violations of human rights and human security in a state cannot be contained in that one state alone. This perspective reveals an intrinsic aspect of human security: all humankind is inextricably connected. ${ }^{16}$

Human security represents a challenge to the traditional notion of security, which has been dominated by a realpolitik security perspective, by placing individual human beings at the center of security concerns. Theoretically, realpolitik security flows from the theory of realism, which emphasizes four features of international relations: (1) statism, (2) anarchy among states, (3) survival of states, and (4) the self-help system. ${ }^{17}$ In essence, realism holds that the state is the preeminent actor and that all other actors in international politics are of lesser significance. ${ }^{18}$

Under realism, state competition for material power brings about the security dilemma from which no state can escape. ${ }^{19}$ The security dilemma occurs when two or more states each feel insecure vis-à-vis

12. David P. Fidler, Public Health and National Security in the Global Age: Infectious Diseases, Bioterrorism, and Realpolitik, 35 GEO. WASH. INT’L L. REv. 788, 810 (2003).

13. Id.

14. Matthew Weissberg, Conceptualizing Human Security, 13 SwORD \& PloughshaRes 3, 7 (2003).

15. Human security generally contextualizes the threats to the daily life of people multi-dimensionally. For example, it deals with the problem of public health, especially the prevalence of infectious diseases, in combination with poverty and underdevelopment. See BERTRAND G. RAMCHARAN, Human RIGHTS AND HUMAN SECURITY 31-49 (2002).

16. Weissberg, supra note 14 , at 4-5.

17. Tim Dunne \& Brian C. Schmidt, Realism, in The Globalization of WorlD POLITICS: AN INTRODUCTION TO INTERNATIONAL RELATIONS 141, 150-55 (John Baylis \& Steve Smith eds., 2nd ed. 2001).

18. Id. at 150-51.

19. On the security dilemma, see John Baylis, International and Global Security in the Post-Cold War Era, in THE GLOBaldZation of World POLITICS: AN INTROduction to INTERNATIONAL RELATIONS, supra note 17 , at $253,257$. 
other states. Under anarchy and the self-help system, no state feels secure, and no state trusts other states not to take aggressive actions. Thus, states make considerable efforts to strengthen their security needs by increasing military forces. One state's effort increases insecurity for other states, and this security dilemma easily leads to tensions, conflict, and war. ${ }^{20}$ Although this dilemma can be mitigated (e.g., through balance of power alliances), realism maintains that it cannot be surmounted as long as states possess ultimate military and material power in a political context characterized by anarchy. Consequently, states have no choice but to pursue power as an overriding imperative. $^{21}$

Because states' military and material capabilities have paramount importance in realpolitik security, this approach takes seriously neither nonmilitary nor nonmaterial capabilities of states, such as human rights, the rule of law, and democratic government. ${ }^{22}$ In this context, nonmilitary or nonmaterial capabilities or attributes of states only matter in realpolitik security to the extent that these capabilities directly affect states' military or material capabilities.

However, under the impacts of globalization, military and material capabilities do not necessarily enhance the security of states. In other words, no matter how much states fortify military capabilities and reinforce alliances with other states for the protection of their security, their efforts may be ineffective against new threats driven by globalization. ${ }^{23}$ These globalized threats make realpolitk security obsolete as a perspective on security issues. In addition, realpolitik security has little to offer conceptually or practically in terms of policies for addressing the new transnational security concerns fueled by globalization. In this sense, the attempt of human security to place the protection of individual human beings before that of the state directly challenges essentially every aspect of realpolitk security.

The rise of human security as a concept in international relations and international law has been fueled by the convergence of the latest phase of globalization and the strengthening of the global human rights movement. First, the loss of power and control by states and intergovernmental organizations caused by the turbulence of globalization creates, or, perhaps, exacerbates, potential new threats to

20. Id.

21. Edward A. Kolodziej, Security Theory: Six Paradigms Searching for Security, in MilleNNIAL REFLeCTIONS ON INTERnational STUdies 547, 551 (Michael Brecher \& Frank Harvey eds., 2002).

22. Fidler, supra note 12 , at 802-03.

23. See Donald M. Snow, National Security for a New Era: Globalization and GEOPOLITICS 155-60, 243-50, 282-95 (2004). 
individual lives. Many individuals are exposed to various threats that have become increasingly transnationalized, such as corruption, repression, discrimination, extreme poverty, and disease. These threats cannot be addressed effectively within the traditional structure and dynamics of the Westphalian state system, exposing its myopic perspective on what constitutes a security threat. ${ }^{24}$ Thus, there is an urgent necessity to reconsider globalized security concerns that directly affect the daily life of individuals.

Second, the human rights movement has made a critical contribution to the emergence of the idea of human security. The concept of human rights contains a fundamental belief in the indivisibility of security and human rights. ${ }^{25}$ This belief well suits the insecurities individuals face in a world of globalized problems. Under the indivisibility of security and human rights, there can be no security for individuals if the right to life is endangered. Similarly, security is also absent when individuals are denied the right to subsistence through the denial of food, clothing, or housing. If security is defined as protection from harm, then the infringement of fundamental rights creates insecurity. ${ }^{26}$ In this context, the expanding activities of NGOs, such as Amnesty International, Doctors Without Borders, and the International Committee of the Red Cross, reflect this linkage between security and human rights. In sum, the indivisibility of security and human rights, stimulated by the human rights movement, can be considered an essential factor contributing to the rise of human security.

Although human security represents a powerful perspective in the age of globalization, there are debates about the definition, applicability, and relevance of human security in international relations today. ${ }^{27}$ The most powerful criticism of human security is that it is an overly broad and obscure concept of security. ${ }^{28}$ The lack of a precise scope and definition of human security makes the tenets of human security appear meaningless, especially to policy makers. Moreover, even scholars who claim that human security has relevance do not suggest that the human

24. Tim Dunne \& Nicholas J. Wheeler, 'We the Peoples': Contending Discourses of Security in Human Rights Theory and Practice, 18 INT'L REL. 9, 12 (2004).

25. Id. at 18.

26. Id.

27. See Taylor Owen, Human Security-Conflict, Critique, and Consensus: Colloquium Remarks and a Proposal for a Threshold-Based Definition, 35 SEC. DIALOGUE 373 (2004) (summarizing human security debates).

28. See Roland Paris, Human Security: Paradigm Shift or Hot Air?, 26 INT'L SEC. 87, 94-95 (2001). 
security approach embodies a unified approach to security. ${ }^{29}$ Paris notes, for example, that "the existing definition of human security tends to be extraordinarily expansive and vague, encompassing everything from physical security to psychological well-being, which provides policymakers with little guidance in the prioritization of competing policy goals and academics little sense of what, exactly, is to be studied." ${ }^{30}$

Human security comes under sharp critique because of its skepticism about states and the role of state-centric international organizations in security concerns. Although human security's emphasis on the importance of nonstate actors may be relevant given globalization's impacts and the growing power of human rights thinking, it has a somewhat skeptical view of the potential for cooperation among states and intergovernmental organizations. However, states and intergovernmental organizations still play an essential role in managing global security, however defined, because states still retain enormous material power. ${ }^{31}$ In fact, the elaboration and development of human security policies require multidimensional cooperation among states and intergovernmental organizations. For instance, official development assistance from developed countries to developing countries plays a huge role in reducing extreme poverty. ${ }^{32}$ Additionally, as explored below, Japan's commitment to the concept of human security is largely expressed through its development aid programs. Moreover, considering the efforts of the World Trade Organization (WTO) on economic growth and the impact of international trade on poverty reduction in many countries, the U.N. Secretary-General has advocated closer and more productive cooperation between the U.N. and WTO. ${ }^{33}$

Despite the controversies surrounding the concept of human security, the idea has arrived as an important aspect of the dialogue in

29. For example, King and Murray simply suggest that only the matters that people would be willing to fight over can be the content of the human security perspective. See Gary King \& Christopher J. L. Murray, Rethinking Human Security, 116 PoL. Sc. Q. 585, 593 (2002).

30. Paris, supra note 28 , at 88 .

31. The U.N. has been making a significant effort to elaborate and develop human security. On the recent elaboration and development of human security, see Human Security Now, supra note 5; U.N. DEP'T OF PUB. INFO., REPORT OF THE SECRETARYGeneral's High-Level Panel on Threats, Challenges and Change, A More Secure WORLD: OUR SHARED RESPONSIBILITY, U.N. Sales No. E.05.I.5 (2004); U.N. DEP'T OF PUB. INFO., REPORT OF THE SECRETARY-GENERAL-IN LARGER FREEDOM: TOWARDS DEVELOPMENT, SECURITY AND HUMAN RIGHTS FOR ALL, U.N. Sales No. E.05.I.15 (2005) [hereinafter IN LARGER FREEDOM].

32. IN LARGER FREEDOM, supra note 31, at 15-17.

33. See id. at 22. 
contemporary international relations generally and in international law and global governance specifically. Problems and skepticism typically stalk ideas on the cutting edge of global politics, and human security is no exception, having its fair share of detractors and opponents. The controversy concerns whether human security is one of the leading normative ideas confronting policy makers in the twenty-first century. Thus, understanding how this concept relates to the potential emergence of an Eastphalian order is worth exploring.

\section{ASIA AS THE LEADING LABORATORY FOR THE FUTURE OF HUMAN SECURITY}

The rise of the human security concept in international relations and the rise of Asia in world affairs have happened simultaneously within the past twenty years. Thinking about human security from the perspective of Asian countries is, thus, more than an academic exercise because whether and how Asian nations accept this concept will have significant impact on the trajectory of this normative reframing of the security debate in national and global governance. This section explores whether the aspects of Asian countries' perspectives on human security offer prospects for Asian countries to become leaders in the development and refinement of the human security concept. In short, the human security debate offers an opportunity to peer into what an Asian perspective on international law and global governance for the early twenty-first century might contain.

The premise of the analysis is not that Asian countries presently have a unitary perspective on human security and its implications for international law and global governance. For example, Japan's embrace of human security as an objective of its foreign policy contrasts with China's and India's more skeptical perspectives and concerns about this concept, especially as it relates to the principles of sovereignty and noninterference. Not surprisingly, many Asian countries have been participating in the arguments about what human security means. ${ }^{34}$ Differences among Asian countries can be seen through viewing attitudes toward human security's close relationship with two kinds of freedom: freedom from fear and freedom from want. Connecting the goal of freedom from want with human security, former U.N. SecretaryGeneral Kofi Annan emphasized that men and women should be free from want so that threats such as extreme poverty and infectious

34. On the different views of human security among Asian countries, see Arabinda Acharya \& Amitav Acharya, Human Security in Asia: Conceptual Ambiguities and Common Understanding, at 12-18 (Feb. 12, 2001), (transcript available at http://www.yorku.ca/robarts/archives/chandigarth/pdf/acharya_delhi.pdf). 
diseases are lifted from their lives. ${ }^{35}$ With respect to freedom from fear, Annan noted that "the threats to peace and security in the twenty-first century include not just international war and conflict but civil violence, organized crime, terrorism, and weapons of mass destruction. They also include poverty, deadly infectious disease and environmental degradation, since these can have equally catastrophic consequences.",36 In terms of freedom from fear, the Secretary-General stressed that all men and women should be free from fear so that their lives and livelihood are not ripped apart by violence, war, and other forces destructive to individual and social safety and security. ${ }^{37}$

The freedom from fear and freedom from want concepts circulate in Asian debates about human security. Anwar notes the following:

[A]lthough the two dimensions of human securityfreedom from needs and freedom from fear-have been emphasized equally in official documents, it is no secret that for most NGOs and observers in Asia the main focus of interest is freedom from fear. Although overcoming poverty is important, there has been very little debate about the subject at either the national or the regional level. ${ }^{38}$

Contrary to Anwar's observation, some Asian states have criticized linking human security too closely with freedom from fear. For example, while acknowledging the two elements of human security, Japan criticizes those who focus solely on freedom from fear. One Japanese official stated:

[H]uman security is a much broader concept. We believe that freedom from want is no less critical than freedom from fear. So long as its objectives are to ensure the survival and dignity of individuals as human beings, it is necessary to go beyond thinking of human security solely in terms of protecting human life in conflict situations. ${ }^{39}$

35. IN LARGER FREEDOM, supra note 31, at 6.

36. Id. at 33 .

37. Id. at 6.

38. Dewi Fortuna Anwar, Human Security: An Intractable Problem in Asia, in ASIAN SECURITY ORDER: INSTRUMENTAL AND NORMATIVE FEATURES 536, 541 (Muthiah Alagappa ed., 2003).

39. Yukio Takaso, Director-General, Foreign Ministry of Japan, Statement at the International Conference on Human Security in a Globalized World (May 8, 2000), cited in Archarya \& Archarya, supra note 34, at 15. 
More important analytically than such differences over where the emphasis in human security ought to be placed is whether Asian perspectives on international relations are conducive or receptive to either the freedom from fear or freedom from want aspects of the human security concept. As explored above, the human security concept involves a radical challenge to traditional ways of thinking about security. Human security changes the focus of the security debate away from the state and toward the individual. Almost by definition, human security looks past sovereignty to peer inside the state and assess how the state secures freedom from fear and freedom from want. The human security concept is heavily influenced by human rights principles; thus, the substantive content of human security has a universal quality across nations and cultures.

Finally, the human security project seems interested in holding states accountable for how they secure freedom from fear and want for their citizens. In short, pursuing human security involves the need to intervene in the domestic affairs of states to assess, admonish, or assist efforts to increase each individual's freedom from fear and want. When human security is gravely endangered within a state, human security policies embrace the right for other countries to raise questions and even to intervene, perhaps even by military force, under the principle of the responsibility to protect or the more general imperative of humanitarian intervention. The responsibility to protect expressly indicates that the foundation of this principle lies in obligations inherent in the concept of sovereignty. ${ }^{40}$ Furthermore, the responsibility to protect principle asserts that where a population is suffering serious harm as a result of internal war, insurgency, repression, or state failure, and the state in question is unwilling or unable to halt or avert it, the principle of nonintervention yields to the international responsibility to protect. ${ }^{41}$

In all these respects, the human security concept is quintessentially post-Westphalian because it challenges the traditional notion of sovereignty, tests sovereignty against a universal standard of human treatment, and advocates for intervention into the domestic affairs of states that do not work toward providing their people with freedom from fear and want. However, the general positions of Asian countries, especially with their emphasis on sovereignty and noninterference, do not embrace the post-Westphalian features of human security, such as

40. Int'l Comm'n on Intervention and State Sovereignty [ICISS], The Responsibility to Protect: Report of the International Commission on Intervention and State Sovereignty, at $\mathrm{XI}$ (Dec. 2001), available at http://www.iciss.ca/pdf/Commission-Report.pdf.

41. Id. 
humanitarian intervention under the principle of the responsibility to protect or building transnational civil society networks to bring pressure to bear on national governments.

The presence of many types of threats to all aspects of human security in Asia makes the region a potentially leading policy laboratory for this concept. A brief examination of the approaches taken by the three big Asian powers-Japan, China, and India-reveals different perspectives that reflect a complex picture of human security. As mentioned above, Japan has made human security a central feature of its foreign policy through, for example, providing support for the work of the Commission on Human Security and funding a Trust Fund for Human Security within the United Nations. Japan also views its development assistance to many countries as a feature of its work to improve human security.

However, the Japanese embrace of human security as a policy objective has some interesting features. First, as one of the world's most affluent, advanced, and stable democracies, Japan does not face much, if any, human security scrutiny of its domestic affairs by other countries, international organizations, or NGOs. Thus, its emphasis on human security in its external affairs does not have much potential to create a "boomerang" effect on Japan's handling of its domestic affairs. Second, Japan finds the human security approach helpful in raising its political and economic profile in Asia and beyond without raising too many concerns about Japanese national interests and intentions. Third, Japan's implementation of development assistance under its human security agenda does not challenge the sovereignty of recipient states or infringe on the principle of noninterference, especially assistance destined for fellow Asian countries. In sum, Japan's embrace of human security creates no domestic political concerns; conveniently helps Japan's efforts to increase its bilateral, regional, and global political and economic influence; and adheres to the principles of sovereignty and noninterference.

China's position is considerably different. Although ideas animating the concept of human security, such as freedom from want and freedom from fear, resonate with goals the Chinese government has for its people, it remains steadfastly opposed to human security as a basis for outside intervention into its sovereign affairs. For Japan, human security is almost entirely an external project; for China, human security is only a matter of domestic affairs. As Chinese scholar $\mathrm{Li}$ Dongyan observed: 
Chinese human security proponents do not exclude sovereignty security and the principle of nonintervention. Even the most active advocates of human security believe that judgments about the human security situation should be based on domestic judgments, not on judgments by people or governments outside the state. Therefore, human security should not become an excuse for foreign interference in domestic affairs. $^{42}$

The human security picture is perhaps most complicated with respect to India. As with Japan and China, the idea of using human security as a framing concept has been debated and analyzed in India. The range of traditional and nontraditional security threats that India faces gives the human security concept plenty of traction in the context of India's external and internal affairs. India's longstanding commitment to principles of sovereignty and noninterference-and its use of those principles to chastise foreign critics of Indian domestic affairs-leaves India with little basis for making human security an element of its foreign policy and relations with other countries, especially other Asian countries. Aspects of Indian foreign policy that might reflect elements of the human security agenda, such as democracy promotion, have been limited in nature and typically can also be explained by Indian geopolitical interests. ${ }^{43}$ Indian bilateral relations and assistance with other countries, such as those in Africa, are predicated on the principles of respect for sovereignty and noninterference. This strategy means that India's efforts to increase its political and economic prominence in the world are not based on advancing a robust notion of human security.

Looking across the Japanese, Chinese, and Indian approaches to human security, the key common theme is clear subordination of human security advocacy to the principles of sovereignty and noninterference in the domestic affairs of states. However, this theme runs counter to what many consider the key aspect of the concept of human security: human security from fear and want cannot be obscured by incantations of

42. Li Dongyan, China's Approach to Non-Traditional Security (NTS) (Mar. 8 2007) (manuscript available at http://ieas.berkeley.edu/events/pdf/2007.03.08_Li_Dongyan.pdf) (last visited Sept. 26, 2009).

43. See Jan Cartwright, India's Regional and International Support for Democracy: Rhetoric or Reality?, 49 ASIAN SURV. 403, 406 (2009) (arguing that "India's apparent increasing support for democracy is predicated more on 'realist' political concerns about the country's strategic and economic interests, rather than an idealistic predisposition to support the spread of 'democracy' as a goal in and of itself'). 
sovereignty and noninterference. In short, the main elements of the Asian perspective on international law and global governance, overall, do not combine in a manner receptive to the prevailing content of the human security concept.

\section{AN EAstPhalian Perspective ON Human SECURITY THROUGH CONFUCIANISM?}

The distinctive Asian perspective on international law and global governance emphasizes principles and rules historically associated with the Westphalian state system. In this context, although the Asian region is a fascinating laboratory for the future of human security, advocacy for more robust national and international action to promote human security faces a fairly hostile environment. Any change that is likely to occur in this situation will have to arise from within the Asian framework, through a connection with Asian ideas and beliefs. This section analyzes whether the philosophical heritage of Confucianism shared by many Asian societies might contain some foundations for an Asian human security perspective that does not stand firmly behind the principles of sovereignty and noninterference. ${ }^{44}$

Philosophically, the Confucian perspective contains features that resonate with the human security idea, particularly the emphasis Confucius and Mencius placed on the ruler's duty to secure his people's physical safety-freedom from fear-and basic material needs-freedom from want. As explored below, Confucianism even contained the idea that one state could intervene with military force in another state whose rulers failed to secure such basic levels of individual security and subsistence. Thus, one can find in Confucian thought features that resemble-if only in a rudimentary way-human security's universal scope, its concern with holding leaders accountable, and its integration of mechanisms to intervene when human security is threatened.

The key concept of Confucianism with regard to world politics can be found in the concepts of Ping and Tian-Xia. According to Confucius, Ping can be understood as peace, harmony, evenness, equality, fairness, justice and the like. For the achievement of Ping, Confucius believed that states and their peoples needed a sense of peace and tranquility

44. Indian civilization, for example, was not as influenced by Confucianism as civilizations in Southeast and East Asian nations, which makes this inquiry into Confucianism of limited prescriptive relevance to Indian attitudes towards human security. 
that transcended territorial borders. ${ }^{45}$ In addition, the optimal world order, which is directed by Tian-Xia, an ideal moral and political order admitting of no territorial boundaries, should be achieved according to the principle of right, virtues, and the aims of Ping. ${ }^{46}$ Thus, Confucius seemed to shut down any possibility of a good war between sovereign states. $^{47}$

However, Confucians recognized two exceptional cases that justified war: self-defense and the limited use of force against tyranny and oppression in other states, which, in Confucian terms, is called "punitive expedition." ${ }^{48}$ Confucians' perspective on self-defense is reflected in Article 51 of the U.N. Charter, and the punitive expedition notion shares, at first glance, some qualities with claims that humanitarian intervention is justified under certain circumstances in international law. The main reason why Confucians allowed two kinds of use of force is evident-protection and promotion of the daily lives of individuals. Ping and Tian-Xia cannot be achieved without the welfare of the people, and Confucians allowed the two uses of force as necessary evils for restoration of the ideal world in situations in the non-ideal world, such as war and armed conflict. Thus, the human security concern with freedom from fear has some equivalent features in the philosophy of Confucius.

When it comes to freedom from want, Confucian teachings also resonate with aspects of the human security idea. Confucians repeatedly stressed that the ultimate goal of states is to secure the basic means of subsistence of people, not to perpetuate the power of an elite ruling class. This Confucian perspective on freedom could justify humanitarian intervention or measures based on a principle of responsibility to protect against a state that fundamentally fails to secure the basic subsistence of its people. Under a Confucian approach, humanitarian intervention is justified in cases in which a foreign ruler or state deliberately denies its population the basic means of subsistence (e.g., intentional starvation), or in which a state has collapsed, exposing the population to widespread famine and starvation. ${ }^{49}$ For instance, if true, the North Korean government's deliberate starvation of its people could trigger a Confucian justification for humanitarian intervention.

45. Frederick Tse-Shyang Chen, The Confucian View of World Order, in THE INFLUENCE OF RELIGION ON THE DEVELOPMENT OF INTERNATIONAL LAW 31, 32 (Mark W. Janis ed., 1991).

46. Daniel A. Bell, Beyond Liberal Democracy: Political THINKING For an East ASIAN CONTEXT 24 (2006).

47. Id.

48. Id. at 36-38.

49. Id. at 47 . 
Considering these fundamental concepts of Confucianism, which focus on the protection of the human being under the rule of Ping and Tian-Xia, a Confucian approach to human security provides reasons why an Eastphalian order could incorporate a concept of human security into international policy without viewing the idea as an imposition on Asian countries by the West. Moreover, a Confucian approach provides philosophical grounds for an Eastphalian order that seeks to establish a more people-centered global order, rather than just a great power dominated, multipolar balance of power.

\section{ACHIEVING Human SECURITY with AN ASIAN FACE: A TASK AT THE HEART OF EASTPHALIA}

Whether Confucian reasoning can produce a more robust Asian approach to human security is, of course, doubtful given the strength of the Asian commitment to sovereignty and noninterference. As noted above, the concept of human security looks past sovereignty and has little patience with states arguing that sovereignty prevents outsiders from assessing their behavior within their own territories. The robust emphasis of Asian countries on the principle of sovereignty and nonintervention conflicts with this aspect of human security because the emphasis values sovereignty more than transnational efforts to develop better human security in all countries. In this respect, Asian countries tend to be consistent and similar because they oppose outside interference in their own affairs. Accordingly, they refrain from criticizing and intervening in each other's domestic affairs. This consistency stands as an obstacle to the need within the human security project for mechanisms to probe the performance of states and intervene when states fail to protect and promote freedom from fear and want.

Other factors also stand in the way of a strong, distinctively Asian notion of human security, particularly the political suspicions that would immediately arise should Japan, China, or India decide to embrace human security policies in a way that involves more interference with other states' domestic affairs. Japan's unfortunate historical legacy in Asia from the 1930s and 1940s serves as one reason why it can only implement its human security policies in the region in ways that do not threaten sovereignty and noninterference. Suspicions about Chinese power and influence are also present, making countries highly attuned to any shifts in Chinese policies that would amount to intervention, however softly peddled. In addition, an Indian push for sharper-edged human security policies would give countries an opportunity for them to play the "China card" and threaten to cooperate more closely politically and economically with China rather than India. 
More conceptually, the attitudes of Asian countries toward the human security idea also serve as a reminder that many in Asia reject the universalism of values as a premise for international law and global governance because, in the experience of Asian countries, universalism is typically pushed by those seeking to exercise superior power. This attitude extends back to Asian participation in efforts by developing countries during the Cold War to stress the importance of peaceful coexistence (e.g., the Five Principles of Peaceful Coexistence and the Bandung Spirit ${ }^{50}$, an approach based on respecting the political, economic, and cultural differences among states.

However much the rhetoric surrounding human security is universalized, the concept is still associated with ideas and values thus far promoted mainly by developed Western countries. Continued advocacy for Asian countries' distinctiveness reveals a skepticism about, and opposition to, viewing Western values as the template for governance in societies with different civilizational and political histories. Approaching human security should, therefore, be a more conservative undertaking that respects different traditions and conceptions of the good society, and this is precisely what we see in the very different approaches of Japan, China, and India.

Two other elements of the Asian perspective augment this more conservative take on human security. First, as noted above, the skepticism about universal values relates directly back to the political experiences of Asian peoples as the victims of Western imperial power and prejudice. The Asian perspective stands as a warning of the dangers of pretending that power and principle are not two sides of the same coin in international affairs. Second, in human security terms, the Asian perspective has focused more attention on economic, social, and cultural rights, which by their very nature and design in international law are relative to a country's level of political, economic, and social development. In short, beyond perhaps some minimal core content, economic, social, and cultural rights lack clear universally applicable meaning, unlike most Western-backed civil and political rights. This context gives human security as freedom from want less traction as a clear universal requirement of good governance.

Frustration in the West with Asian preference for principles of nearabsolute sovereignty and nonintervention arise in part because the Asian perspective does not appear to contain any positive ideas on how states should deal with atrocities, oppression, and failure to provide basic subsistence taking place in other countries. The contrast between

50. See Wang Tieya, International Law in China: Historical and Contemporary Perspectives, 221 ReCUEIL DES CoURS II [Collected CoURSES] 203, 263 (1990) (discussing China's Five Principles of Peaceful Coexistence and the Bandung Spirit). 
Western and Asian perspectives on human security issues, especially humanitarian intervention, are perhaps most stark in connection with Myanmar. Generally speaking, Western countries have favored more interventionist policies for trying to address the nightmare the junta in Myanmar is creating for its people and the region. Asian countries have generally opposed intervention and have been unwilling to engage the junta strongly enough to force a change in policy. This contrast was again present in the wake of the devastating cyclone that struck Myanmar in 2008. ${ }^{51}$

The post-cyclone devastation in Myanmar, combined with the junta's deliberate efforts not to allow foreign humanitarian assistance to reach desperate populations, created a humanitarian crisis that Confucianism might recognize as a candidate for justified humanitarian intervention. The cyclone massively threatened the ability of people in Myanmar to access basic survival goods, including food, water, and shelter, and the junta deliberately prevented foreign humanitarian assistance from reaching people facing life-threatening conditions. Confucian conceptions of good governance would recognize nothing the junta did in the aftermath of the cyclone as satisfying the ruler's duties to ensure the basic subsistence needs of his people. The Asian perspective seemed fixated on defending sovereignty and the principle of nonintervention at all costs. Undoubtedly, Asian countries offered Myanmar support and disaster relief supplies, but there is no evidence of a concerted effort made by Asian countries to prod Myanmar to perform more effectively in responding to this disaster. No Asian version of a "responsibility to protect" principle was present in this episode.

Measured against the quintessentially post-Westphalian concept of human security, the Eastphalian approach looks rather Westphalian in comparison because of its continued emphasis on sovereignty and nonintervention into the domestic affairs of states. The Asian perspective raises, however, hard questions about the post-Westphalian conception of human security and its future. The most important of these questions is whether the prevailing concept of human security and its corollary-the principle of the responsibility to protect-constitute the best approach for states and the international community to achieve freedom from fear and freedom from want. From the Asian perspective, the concept of human security looks like another "one size fits all" solution advocated by Western countries and human rights advocates

51. On the situation in Myanmar as it relates to humanitarian intervention, see Madeleine K. Albright, The End of Intervention, N.Y. TIMES, June 11, 2008, at A23; Saw Yan Naing, Humanitarian Intervention Calls Increase, THE IRRAWADDY, May 12, 2008, available at http://www.irrawaddy.org/article.php?art_id=11982. 
that ignores the progress Asia has made as a region in advancing freedom from fear and freedom from want without diluting sovereignty and engaging in interventions.

For example, the U.N. reported that Asia's economic growth has reduced extreme poverty and hunger dramatically, which is the first of the Millennium Development Goals. ${ }^{52}$ Progress on reducing extreme poverty and hunger qualifies as direct progress on increasing freedom from want within the region. Further, the larger political impacts of higher standards of living indirectly reduce the threat of civil unrest and conflict, thus supporting freedom from fear. Despite tensions and differences, Asian countries have also avoided becoming engaged in interstate wars as the region has grown in economic and political significance. The absence of such wars strengthens freedom from fear within the region as well. These achievements in Asia are, of course, linked to other global phenomena, such as the foundation for global trade provided by WTO, and to active Asian participation in the workings of international and regional governance, such as the United Nations and ASEAN. Nevertheless, avoiding large-scale wars, significantly increasing economic growth, and reducing extreme poverty and hunger are noteworthy human security achievements within the Asian region that were accomplished without subordinating sovereignty or fostering interventionist policies.

In short, the dissonance between the prevailing concept of human security and elements of the Asian perspective on international relations should not imply that Asian countries have failed to improve human security. Asian nations have made improvements, in fact, by following a different approach than the one found in the human security project associated with the continued attempt to universalize Western liberalism. The gains made in Asia do not mean that human security problems are few or far between in Asian countries. Asia today contains the best of the first world and the worst of the third world, which makes the region such a fascinating potential laboratory for global governance on human security.

The Eastphalian recipe for dealing with human security problems is, however, more conservative and Westphalian than the prevailing concept of human security pushed in the West. At the macro-political level, this recipe involves robust national engagement with the global economic and financial system as a means of increasing national and regional economic and material wealth, in addition to strenuous efforts to avoid interstate war and conflict. These strategies require no radical

52. U.N. Dep't of Econ. \& Soc. Affairs, The Millennium Development Goals Report 2005, at 6 (2005), available at http://unstats.un.org/unsd/mi/pdf/MDG\%20Book.pdf. 
revisions of existing bodies of international law on the use of force and international economic cooperation. In terms of how each country internally manages its economic and political affairs, the Eastphalian approach stresses the need for each government to understand and faithfully honor the duty it owes to provide security and subsistence for its people. In the Eastphalian context, this duty is informed more by the importance of economic, social, and cultural rights than Western practices stressing civil and political rights.

How any individual government specifically fulfills its duty is not a basis for foreign interference and intervention into its domestic affairs. The Eastphalian approach is tolerant of differences in governmental regimes, economic systems, and cultural traditions. Changes to such regimes, systems, and traditions will occur, particularly in the context of intensifying globalization, but the changes should be as indigenous as possible and flow from within the country rather than being imposed or manipulated from without. Both the philosophical heritage and historical political experiences of Asian countries tend to equate foreign intolerance of differences with the arrogant ambition of superior power. Thus, the Eastphalian perspective can embrace human security as an objective but can also differ from Western champions of this idea in how states and societies should pursue this objective. The Eastphalian approach to human security does not give international law and global governance mechanisms much leverage, if any, in terms of advancing human security globally.

\section{CONCLUSION: The DESTINY OF HUMAN SECURITY IN AN EASTPHALIA ORDER}

The Asian perspective on human security is important for international law and global governance in the future because this concept emerged in the post-Cold War period as a leading normative development with deep implications for international law and global governance. As discussed in this article, the Asian approach to international relations and the prevailing post-Westphalian nature of the human security concept do not share much, if any, common ground. In short, the Asian perspective offers little for advocates of human security to embrace.

This fundamental divergence is not about the importance of governments working towards freedom from fear and freedom from want; rather, the divergence appears in how states should go about engaging each other in the pursuit of these objectives. Asian countries can claim that their approach leads to gains in human security, as illustrated by the absence of interstate wars among Asian countries and 
the significant reductions in extreme poverty and hunger Asian countries have made through economic growth. All the attention to the rise of Asia must mean that Asian countries have more to offer to the conceptualization of human security than empty incantations about the absolute nature of the principles of sovereignty and nonintervention.

But what exactly Asian countries have to offer in terms of the idea of human security within an Asian-centric international system is still difficult to describe. At present, the best description might be that Asian countries accept that human security is important but that its achievement remains the exclusive domain of the sovereign state and cannot serve as the basis for interference with domestic affairs. In other words, human security's importance is primarily a matter for domestic politics according to each country's own political system and traditions. This approach, of course, leaves international law and global governance with no direct role in fostering human security, a proposition unlikely to be welcomed by human security proponents with a more jaundiced view of sovereignty and more faith in transnational activism on behalf of universal human rights within a more radical understanding of the roles of international law and global governance.

The emergence of an Eastphalian order will not quiet discontent among those who believe that sovereignty and nonintervention are barriers to global human progress. However, the combination of growing Asian material power and political influence, Asian commitment to the principles of sovereignty and nonintervention, and Asian diplomatic practices that adhere to those principles will make an Asian-centric international system a harsher environment for the concept of human security than the Western-dominated, post-Westphalian period ushered in by the end of the Cold War. This difficult transition into Eastphalia for the concept of human security will only be eased if Asian powers take active steps to incorporate human security thinking more robustly into their responsibilities in the new world order. At present, the prospects for such a change are slim, and any idea of what such change might actually look like remains a mystery. 
